\title{
Milk Quality on Danish Farms with Automatic Milking Systems
}

\author{
M. D. Rasmussen, ${ }^{*}$ M. Bjerring, ${ }^{*} P$. Justesen, $\dagger$ and L. Jepsen $\dagger$ \\ *Dept. of Animal Health and Welfare, Danish Institute of Agricultural Sciences, \\ DK-8830 Tjele, Denmark \\ †Veterinary and Milk Quality Department, Danish Dairy Board, \\ DK-8000 Aarhus C, Denmark
}

\begin{abstract}
The bulk-milk quality of 98 Danish farms with automatic milking systems was analyzed from 1 yr before introduction of automatic milking until $1 \mathrm{yr}$ after. Bulkmilk total bacterial count, spores of anaerobes, somatic cell count (SCC), and freezing point increased when automatic milking was introduced and the frequency of milk-quality failures almost doubled. Milk-quality failures were most frequent in the first 3 mo after the start of automatic milking. The increase in spores of anaerobes indicated that the increase in total bacterial count originated partly from contamination of milk from the teat surface and partly from lack of cleaning of the milking equipment or cooling of the milk. The increase in bulk-milk SCC indicated that milk from clinically infected cows and cows with high cell counts was not diverted to the same degree, milking automatically rather than milking conventionally. A self-monitoring program including survey of the bulk-milk quality was established to help farmers in the transition period going from conventional to automatic milking. The program was introduced on 84 farms. Farms on the self-monitoring program reduced bulk-milk cell count. Application of the program did not reduce the frequency of high total bacterial counts and freezing points of the bulk milk to the level of conventional milking. However, the program reduced the overall frequency of milk-quality failures.
\end{abstract}

(Key words: automatic milking, somatic cell count, total bacterial count, freezing point)

Abbreviation key: $\mathbf{S C C}=$ somatic cell count, $\mathbf{A M S}=$ automatic milking system, $\mathbf{T B C}=$ total bacterial count.

\section{INTRODUCTION}

Automatic milking implies that cows are milked automatically according to their diurnal routine. Addition-

Received October 2, 2001.

Accepted May 17, 2002.

Corresponding author: M. D. Rasmussen; e-mail: MortenD. Rasmussen@agrsci.dk. ally, the system offers more flexible working hours for farmers and, thereby, a possibility of a better social life (Lind et al., 2000). The first commercial farm was equipped with an automatic milking system (AMS) in 1992 in the Netherlands. AMS was first introduced to farms in Denmark in February 1998. Since then, much interest has developed, and about 100 Danish farms were equipped with AMS at the end of 2000 (Figure 1). We expect that considerably more Danish dairy farms will invest in AMS. Reports from The Netherlands indicate that the total bacterial count (TBC), SCC, freezing point, and level of FFA of the bulk milk may be altered by the introduction of AMS (Jepsen and Rasmussen, 2000; Klungel et al., 1998; 2000; Vorst and Hogeveen, 2000). Consequently, automatic milking could potentially have a major influence on Danish milk quality.

The most common method of detecting abnormalities in milk from cows milked automatically is measuring electrical conductivity. An attention list is produced based on algorithms comparing the individual quarters and/or historical data either of quarters or of composite milk. Milk conductivity as the only measure of milk quality appears to be insufficient for the detection of clinical mastitis (Knappstein et al., 1998). Hamann and Zecconi (1998) concluded from a meta analysis of available literature that electrical conductivity does not identify mastitic quarters or cows with sufficient accuracy. Sensitivity for detection of clinical mastitis was reported from 33 to $95 \%$ and specificity from 71 to $100 \%$. Nielen et al. (1995) reported that the detection rate increased when milk production and temperature were added to the statistical models and found a sensitivity of $75 \%$ and specificity of $90 \%$ for detection of clinical mastitis. Work by DeMol (2000) has shown that improvements of algorithms and combination of measurement of conductivity, temperature, and milk yield further improved sensitivity and specificity. However, Hogeveen et al. (2001) conclude that sensors of AMS need to more precisely measure the factors of interest. Therefore, to sort milk according to the EU Hygiene Directive 89/362 and Pasteurized Milk Ordinance (USA), abnormal milk should be measured more directly.

In general, the current generation of AMS does not sort milk according to the appearance of the foremilk, 


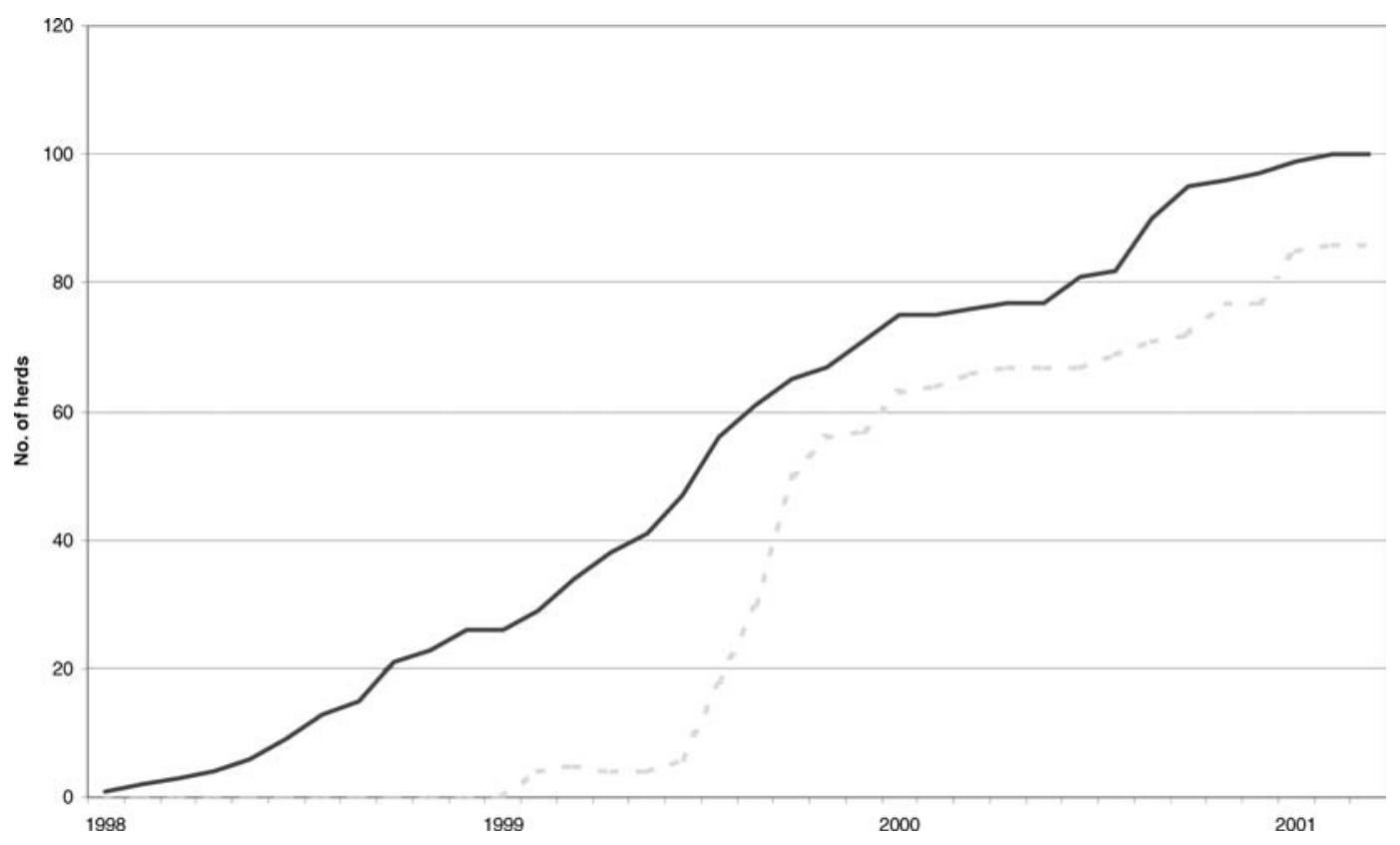

Figure 1. Number of farms with automatic milking in Denmark (black line) and farms enrolled in the self-monitoring program (dotted line).

and, consequently, AMS can not be used according to the EU Hygiene Directive 89/362. For a test period the Danish Ministry of Food, Agriculture, and Fisheries has approved that general visual inspection of foremilk may be abolished for AMS if the model is tested by the Danish Institute of Agricultural Sciences to define and describe conditions for a self-monitoring program (Rasmussen and Jepsen, 2000). Additionally, farmers have to participate in this program and the supervision of milk quality in case of failures. Farmers who do not participate are required to carry out daily visual inspection of foremilk. The Danish AMS self-monitoring program was set up to reduce the impact of clinically infected cows on bulk-milk SCC and to help farmers in the transition period going from conventional to automatic milking. This paper reports the milk quality of Danish farms with AMS from the very first installations and of the first $2 \mathrm{yr}$ of the self-monitoring program.

\section{MATERIALS AND METHODS}

\section{Data Collection}

AMS companies reported the date of installation of all AMS on farms in Denmark to the Danish Dairy Board. For all farms converting to AMS, milk-quality data of bulk milk before and after conversion were extracted from the national database including SCC, TBC, spores of anaerobes, and freezing point. This database includes milk quality of all routine measurements on bulk milk from Danish dairy farms. Milk-quality data were extracted from $1 \mathrm{yr}$ before installation of the first AMS (February 1997) until March 2001, which then includes $3 \mathrm{mo}$ of data for the last started farm in 2000. Additionally, weekly mean bulk milk-quality of all dairy farms (national averages) was included for comparison for 1998 to 2000. Bulk milk was sampled weekly for analysis of SCC and TBC by a Fossomatic 5000 and Bactoscan 8000 S (Foss Electric, Hillerød, Denmark). Bulk milk was sampled every 12 wk for the analysis of spores of anaerobes and freezing point. Spores of anaerobes were analyzed by MPN-technique (IDF, 1969). Freezing point was analyzed by a calibrated Milkoscan 5000 (Foss Electric). Freezing points above $-0.516^{\circ} \mathrm{C}$ were verified on cryoscope.

\section{Farms Included}

At the end of 2000, 98 Danish farms had installed AMS. The self-monitoring program was introduced to 84 farms. One farm stopped after 11 mo of AMS use and before the self-monitoring program was introduced. The remaining farms had AMS for more than $1 \mathrm{yr}$ before the start of the program, and for three of these farms, the self-monitoring criteria were not yet outlined because their specific AMS model was not officially tested. The evolution in the number of AMS herds and of the participation in the self-monitoring program are shown in Figure 1. Bulk-milk quality data of all farms were included from $1 \mathrm{yr}$ before start of automatic milking. Bulk-milk quality data of all AMS farms were included 


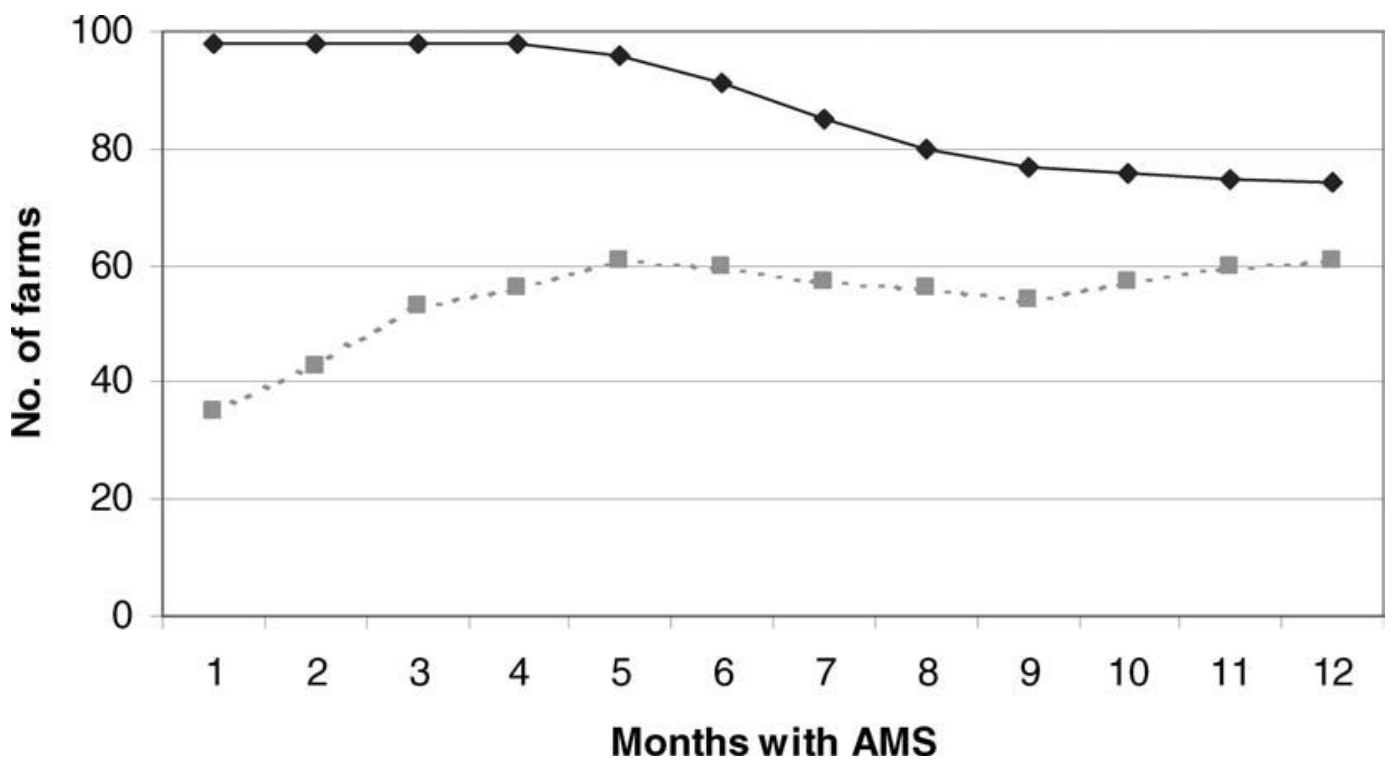

Figure 2. Number of farms in the study (black line) relative to the of start automatic milking and number of those farms enrolled in the self-monitoring program (dotted line). AMS = Automatic milking system.

in the statistical analysis up to $1 \mathrm{yr}$ after the start of automatic milking. Number of farms with AMS and number of relative to the start of AMS and farms on the self-monitoring program are shown for the first year (the year of data analysis) in Figure 2. Farms starting with AMS in 1998 were not enrolled in the self-monitoring program in their first months, and farms starting with AMS in 2000 did not have a full year of data included, consequently, the number of farms with AMS then decreases.

\section{The Self-Monitoring Program}

The self-monitoring program is based on supplementary requirements to the specific type of AMS following the official Danish test (Rasmussen and Jepsen, 2000). For AMS models that do not sort milk according to quality at the time of milking, the main goal is to exclude clinically infected cows from the herd before introduction of AMS. Herds must participate in the official milk-yield monitoring system (DHI), and all treatments of animals are filed in the national cattle database either by the veterinarian or by the farmer. The program includes four parts:

1. Introduction to supplementary requirements, self-monitoring, logbook, and filing of treated animals. A milk-quality advisor will give the farmer an introduction to AMS model-specific supplementary criteria and self-monitoring of animal health and welfare. All cows are foremilk stripped to find clinically infected cows and cows with CMT-score 5. These cows must either be culled or treated before they are milked automatically. Special attention will be given to handling of cows on alarm lists and how a logbook is written. Filing of treated animals will be discussed. The first visit is preferred to take place before start of AMS at the farm.

2. Visit by a milk quality advisor during the first 3 mo. Every farm will be visited 1 and 3 mo after the introduction to part 1. Visual inspection and CMT-score are performed of all cows delivering milk for consumption, and results are compared with notes in the logbook, alarm lists, and individual cow SCC from the milk-yield recording. Milk-quality data are discussed. If there are serious disagreements between test results and notes in the logbook at the second visit, the reasons are clarified and a new visit will be scheduled in 2 mo.

\section{Correction and research into reasons of fail-} ures in milk quality. Milk-quality advisors will contact farmers within a week of fault detection if the milk quality reaches the limits shown in Table 1 . Fault

Table 1. Sampling rates of bulk-milk quality data and thresholds for milk-quality inspectors to contact farmers in case of milk-quality failures. ${ }^{1}$

\begin{tabular}{|c|c|c|c|}
\hline & $\begin{array}{l}\text { Samples } \\
\text { per } 12 \mathrm{wk}\end{array}$ & $\begin{array}{l}\text { Two } \\
\text { consecutive } \\
\text { samples }\end{array}$ & $\begin{array}{l}\text { One } \\
\text { sample }\end{array}$ \\
\hline TBC, per ml & 12 & $>30,000$ & $>100,000$ \\
\hline SCC per ml & 12 & $>300,000$ & $>400,000$ \\
\hline Inhibitors & 3 & & Positive \\
\hline Freezing point, ${ }^{\circ} \mathrm{C}$ & 3 & $>-0.520$ & $>-0.516$ \\
\hline
\end{tabular}

${ }^{1} \mathrm{TBC}=$ Total bacterial count; SCC $=$ somatic cell count. 
detection due to raised TBC-count or freezing point will typically result in additional samples following the milk from cows to the bulk tank. Problems related to high bulk-milk SCC will be clarified by comparing SCC of individual cows with the list of cows delivering milk to the bulk tank. Visual inspection and CMT-score of foremilk will be performed on all cows if agreements are unsatisfactory. Recommendations for lowering the cell count will be given, and an additional visit may be scheduled. The milk-quality advisor will contact the farmer immediately in case of detection of inhibitors in the bulk milk. Reasons for this failure will be clarified.

4. Evaluation after 12 mo (clinically sick animals, animal welfare). Data on milk quality, animal health, detection quality, and filing of data are evaluated at an annual visit of each farm and a report is written. Newly and chronically infected mastitis cows are calculated from the monthly cow SCC. The mean milk quality of same models of automatic milking systems will be used as comparison. Results of these observations are not reported here.

The Danish distributors of AMS pay the costs for the first three visits. Costs for detection of milk-quality failures are split between farmers and distributors.

\section{Statistical Methods}

The changes in percentage of cows with abnormal foremilk or CMT score 5 at visit 1 to 3 in the introductory period of the self-monitoring program were filed for 80 herds and tested using the procedure PROC MIXED (SAS Institute, 1996).

$$
\mathrm{Y}_{\mathrm{ijk}}=\mu+\text { Visit }_{\mathrm{i}}+\text { Herd }_{\mathrm{j}}+\text { YearMonth }_{\mathrm{k}}+\varepsilon_{\mathrm{ijk}},
$$

where

$$
\begin{aligned}
\mathrm{Y}_{\mathrm{ijk}}= & \text { Logit function of percentage of cows } \\
& \text { with abnormal foremilk or cows with } \\
& \text { CMT 5, } \\
\mu= & \text { overall mean, } \\
\text { Visit }_{\mathrm{i}}= & \text { fixed effect of introductory visits }(\mathrm{i}=1, \\
& 2,3), \\
\mathrm{Herd}_{\mathrm{j}}= & \text { Random effect of herd }(\mathrm{j}=1, \ldots, 80), \\
\text { YearMonth }_{\mathrm{k}}= & \text { fixed effect of monthly variations across } \\
& \text { years }(\mathrm{k}=199904, \ldots, 200102), \text { and } \\
\varepsilon_{\mathrm{ijk}}= & \text { residual error } \sim \mathrm{N}\left(0, \sigma^{2}\right) .
\end{aligned}
$$

In general, bulk-milk quality data were analyzed from $1 \mathrm{yr}$ before the start of automatic milking, the first 3 mo after, and the next 9 mo with automatic milking. Bulk-milk SCC, TBC, and spores of anaerobes were transformed with logarithm 10 and freezing point with power 10 to approximate the normal distribution. The data were tested using the statistical procedure PROC MIXED (SAS Institute, 1996).

$$
\begin{gathered}
\mathrm{Y}_{\mathrm{ijklmn}}=\mu+\text { Period }_{\mathrm{i}}+\text { Self-Monitor }_{\mathrm{j}}+\text { Period } \text { Perlor } \\
\text { SSelf-Monitor }_{\mathrm{ij}}+\text { InstYear }_{\mathrm{k}}+\text { YearMonth }_{\mathrm{l}} \\
+ \text { Herd }_{\mathrm{m}}+\text { Date }\left(\text { Herd }_{\mathrm{n}}+\varepsilon_{\mathrm{ijklmn}}\right.
\end{gathered}
$$

where

$\mathrm{Y}_{\mathrm{ijklmn}}=$ logarithm of TBC, SCC, or spores of anaerobes, or power 10 of freezing point,

$\mu=$ overall mean,

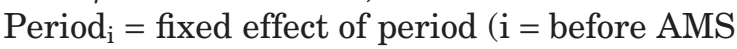
installation, first $3 \mathrm{mo}$, next $9 \mathrm{mo}$ ),

Self-Monitor ${ }_{j}=$ fixed effect of participation in the self-monitoring program $(\mathrm{j}=$ Yes, No),

InstYear $_{\mathrm{k}}=$ fixed effect of tear of AMS installation $(\mathrm{k}=1998,1999,2000)$,

YearMonth $_{1}=$ fixed effect of monthly variations across 4 yr $\mathrm{l}=199702, \ldots, 200103)$,

$\operatorname{Herd}_{\mathrm{m}}=$ random effect of herd $(\mathrm{m}=1, \ldots, 98)$,

Date $(\text { Herd })_{n}=$ the effect of date within herd included as unstructured, repeated function, and

$\varepsilon_{\mathrm{ijklmn}}=$ residual error $\sim \mathrm{N}\left(0, \sigma^{2}\right)$.

The independent variable Year-Month modeled yearly variations across farms, whereas Date(Herd) modeled variations between sampling dates within herd. The function "Repeated" allows different sampling dates to be correlated individually and unstructured.

The statistical procedure PROC GENMOD (SAS Institute, 1996) was used to test the frequency of milkquality failures, which were summed within Herd, Period, and Self-Monitor.

$$
\begin{gathered}
\mathrm{Y}_{\mathrm{ijk}}=\mu+\text { Period }_{\mathrm{i}}+\text { Self-Monitor }_{\mathrm{j}}+\text { Period } \\
\text { Self-Monitor }_{\mathrm{ij}}+\text { Herd }_{\mathrm{k}}+\varepsilon_{\mathrm{ijk}} \\
\text { /link }=\text { logit }, \text { dist }=\text { bin. }
\end{gathered}
$$

Explanations for fixed effects are as for model 2. The logit-function was used for these binary distributed data. Herd was included as the unstructured "Repeated" function.

\section{RESULTS AND DISCUSSION}

\section{Introductory Visits}

The number of cows with abnormal milk or high CMTscore during the first $3 \mathrm{mo}$ is shown in Table 2 . The 
Table 2. Transformed least square means and 10 and $90 \%$ fractiles of cows with abnormal foremilk and CMT-score of 5 observed during the introductory visits of the self-monitoring program to 80 farms.

\begin{tabular}{|c|c|c|c|c|c|c|}
\hline \multirow[b]{2}{*}{ Visit no. } & \multicolumn{3}{|c|}{ Abnormal foremilk } & \multicolumn{3}{|c|}{ CMT-score ${ }^{5}$} \\
\hline & $\%$ Cows & $10 \%$ & $90 \%$ & $\%$ Cows & $10 \%$ & $90 \%$ \\
\hline 1 & $3.7^{\mathrm{a}}$ & 0.6 & 8.2 & $10.1^{\mathrm{a}}$ & 2.9 & 20.8 \\
\hline 2 & $3.0^{\mathrm{ab}}$ & 0.5 & 7.2 & $7.2^{\mathrm{b}}$ & 2.7 & 16.2 \\
\hline 3 & $2.7^{\mathrm{b}}$ & 0.6 & 6.6 & $5.9^{\mathrm{c}}$ & 1.6 & 16.6 \\
\hline
\end{tabular}

a,b,c Significantly different $P<0.05$ within column.

percentage of cows with abnormal foremilk dropped from $3.7 \%$ at the introductory visit to $2.7 \%$ at the third visit $(P<0.05)$. The percentage of cows with a CMT-score of 5 dropped from $10.1 \%$ at the introductory visit of the self-monitoring program to $5.9 \%$ at the third visit $(P<$ 0.001). Several of the farms had very low frequencies of abnormal milk and CMT-score 5. Cows with abnormal foremilk detected at visits by the milk-quality inspectors were a mixture of cows not found by the AMS and of failures by the farmer. Some of the farms did not satisfactorily improve the detection of cows with abnormal foremilk and were visited a fourth time. Table 2 only includes cows delivering milk for consumption, and the actual number of cows with abnormal foremilk in the herds is either the same or higher than the frequencies stated. The reduction in number of cows with abnormal foremilk or CMT-score 5 may just be a side effect of being enrolled in a survey program rather than a direct effect on udder health. Farmers could intentionally have improved separation of cows because they were visited. Nevertheless, farmers then knew how to work with the alarm lists, which was part of the purpose. If possible, the first visit introducing the self-monitoring program should be carried out before start of AMS. Then clinically infected and CMT-score 5 cows can be pointed out before start of AMS, and the AMS has a better possibility of identifying new infections only. In most cases this worked satisfactorily ( $<5 \%$ cows with abnormal milk), and the remaining few cows with high cell counts could be found during the monthly milk yield recording with the individual cow SCC testing. Farms with poor udder health had many cows on the alarm lists daily. The self-monitoring program requires testing of these alarm cows, resulting in a lot of work testing cows for those farms that did not cull or treat infected cows before start of automatic milking. Milk-quality inspectors had the impression that farmers keeping number of infected cows at a minimum had less daily work with the alarm list. Farmers reported that number of false positives on the alarm list was a greater problem than false negatives.

\section{Total Bacterial Count}

The geometric mean of TBC of the bulk milk increased from $7,400 / \mathrm{mL}$ in the year preceding start of milking with AMS to about 14,000/mL milking with AMS (Table 3). No general improvement of TBC occurred by the selfmonitoring program. Geometric means of TBC were high and fluctuating in 1998 when only few herds had AMS (Figure 3). As the number of farms with the self-monitoring program increased, the fluctuations seemed to have lowered (not significantly; Table 4), but the bulk milk TBC was still higher than all Danish herds with conventional milking (Figure 3). Klungel et al. (2000) report a similar increase in bulk-milk TBC. Vorst and Hogeveen (2000) found a larger increase in TBC after the introduction to first-generation farms than to the second-generation. According to their time classification, only secondand third-generation AMS were installed on the Danish farms but may still be first- and second-generation AMSfarmers. Obviously, TBC had still not improved satisfactorily, although the milk still was mainly of premium class. The self-monitoring program does not identify the reason for the higher TBC, but we may speculate that a closer look is needed at the cleaning and cooling systems and the management support of keeping the systems functional. Possible fault detections are now filed, and future evaluations of this data may hint at reasons for high bacterial counts.

\section{Spores of Anaerobes}

Spores of anaerobes in bulk milk increased $(P<0.01)$ going from conventional to automatic milking and stayed higher throughout the first year (Table 3). The cause for the increase from the first to the next period with AMS is not known. There was no statistical difference in spore counts with or without the self-monitoring program. Spores of anaerobes originate from contamination of the teat surface and do not replicate in the milking equipment or during storage. This indicates that contamination of the milk with manure was more pronounced milking automatically than conventionally. Automatic milking should allow the farmer to spend more hours in the barn than by conventional milking and as such leave time for cleaning and bedding of stalls. This opportunity is either not used or the automatic teat-cleaning procedure is not as sufficient as manual cleaning. An increase in spores of anaerobes normally correlates with a parallel increase in TBC, and, consequently, part of the increase in TBC is likely to have originated from contamination of the teat surface.

\section{Somatic Cell Count}

On the farms that converted to AMS, cell counts of bulk milk averaged the same as for conventional Danish herds before the start of AMS (data not shown). Bulkmilk SCC increased after introduction of automatic milk- 
Table 3. Least square means of bulk-milk quality of farms with automatic milking systems and enrolled in the self-monitoring program.

\begin{tabular}{|c|c|c|c|c|c|c|c|c|}
\hline Self-monitoring program & $\frac{\text { Previous year }}{\text { No }}$ & \multicolumn{2}{|c|}{ First 3 mo with AMS } & \multicolumn{2}{|c|}{ Next 9 mo with AMS } & \multicolumn{3}{|c|}{ Levels of significance } \\
\hline No. of farms & 98 & $78^{1}$ & $53^{1}$ & $44^{1}$ & $84^{1}$ & & & \\
\hline Total bacterial count, $1000 / \mathrm{mL}$ & 7.4 & 14.6 & 13.1 & 13.0 & 13.6 & & & \\
\hline Spores of anaerobes, log & $2.56^{\mathrm{a}}$ & $2.67^{\mathrm{b}}$ & $2.71^{\mathrm{b}}$ & $2.83^{\mathrm{c}}$ & $2.80^{\mathrm{c}}$ & $* *$ & $\mathrm{NS}^{3}$ & NS \\
\hline Spores of anaerobes, /L & 359 & 471 & 514 & 673 & 629 & & & \\
\hline SCC, $\log$ & $5.39^{\mathrm{a}}$ & $5.48^{\mathrm{d}}$ & $5.42^{\mathrm{b}}$ & $5.45^{\mathrm{c}}$ & $5.41^{\mathrm{b}}$ & $* * *$ & $* * *$ & * \\
\hline Freezing point, ${ }^{\circ} \mathrm{C}$ & -0.525 & -0.518 & -0.517 & -0.518 & -0.518 & & & \\
\hline
\end{tabular}

a,b,c,d Significantly different within row, $P<0.05$. Levels of significance of fixed effects are indicated as $* P<0.05, * * P<0.01, * * * P<0.001$.

${ }^{1}$ Some farms introduced the self-monitoring program within the 3 - and 9-mo period.

${ }^{2}$ The statistical model including self-monitor and the interaction Period·Self-Monitor had infinite likelihood and did not meet the convergence criteria. LSMean values are from an unrepeated statistical analysis.

${ }^{3}$ The statistical model including the main effect of Self-Monitor had infinite likelihood. LSMean values are from a model without this effect. $\mathrm{SCC}$ = somatic cell count; AMS = automatic milking system.

ing $(P<0.001)$. Bulk-milk SCC increased more $(P<$ $0.001)$ in the first 3 mo milking with AMS on the farms not enrolled than those enrolled in the self-monitoring program (Table 3 ). This effect may be due to exclusion of clinically infected cows after introduction of the self- monitoring program. The difference between the two groups was measurable for the whole year after the start of milking with AMS (Table 3). Farms that started with AMS in 2000 had higher SCC than farms starting in 1998 and $1999(P<0.05$, data not shown), but no general

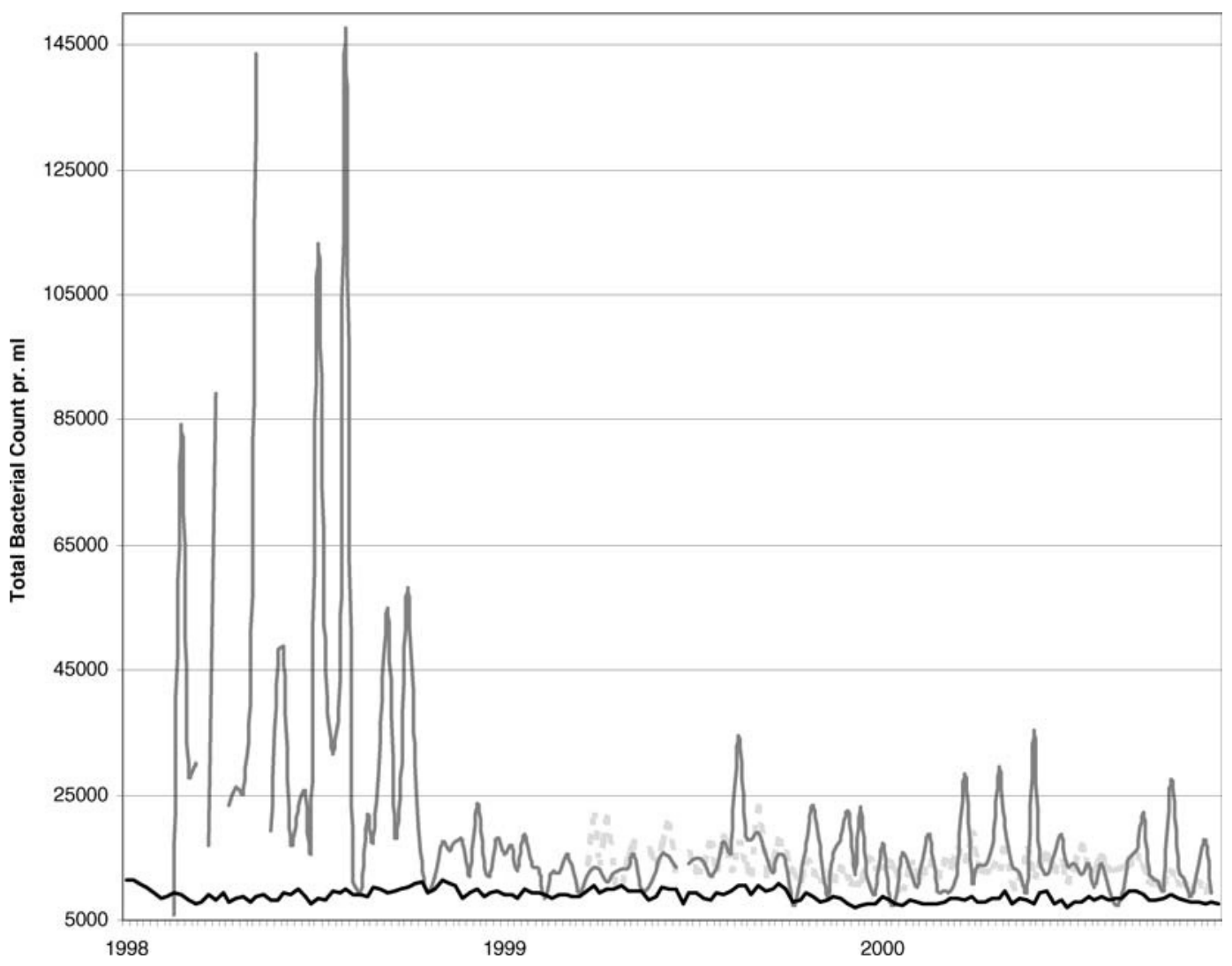

Figure 3. Geometric means of total bacterial count of bulk milk of all Danish farms (black line), farms with automatic milking not enrolled in the self-monitoring program (gray line), and farms with automatic milking enrolled in the self-monitoring program (dotted line). 
Table 4. The percentage of bulk-milk samples (simple means) above limits for fault detection of the milk quality of farms enrolled in the self-monitoring program and for farms without the program. Low limits were two consecutive samples above: $30,000 \mathrm{bacteria} / \mathrm{mL}$ or 300,000 cells $/ \mathrm{mL}$ or $-0.520^{\circ} \mathrm{C}$. High limits were one sample above: 100,000 bacteria $/ \mathrm{mL}$ or 400,000 cells $/ \mathrm{mL}$ or $-0.516^{\circ} \mathrm{C}$.

\begin{tabular}{|c|c|c|c|c|c|c|c|c|}
\hline Self-monitoring program & $\frac{\text { Previous year }}{\text { No }}$ & \multicolumn{2}{|c|}{ First 3 mo with AMS } & \multicolumn{2}{|c|}{ Next 9 mo with AMS } & \multicolumn{3}{|c|}{ Levels of significance } \\
\hline Total no. of samples & 5,090 & 770 & 535 & 1,180 & 2,273 & & & \\
\hline Total bact. count $>100$ 000/mL & $1.0^{\mathrm{a}}$ & $4.5^{\mathrm{b}}$ & $2.9^{\mathrm{b}}$ & $2.8^{\mathrm{b}}$ & $3.1^{\mathrm{b}}$ & $* * *$ & NS & NS \\
\hline $\mathrm{SCC}>300000 / \mathrm{mL}$ & 8.9 & 9.3 & 7.4 & 10.2 & 7.9 & NS & NS & NS \\
\hline $\mathrm{SCC}>400000 / \mathrm{mL}$ & $8.7^{\mathrm{a}}$ & $25.4^{\mathrm{c}}$ & $11.0^{\mathrm{ab}}$ & $14.7^{\mathrm{b}}$ & $8.8^{\mathrm{a}}$ & $* * *$ & $* * *$ & $*$ \\
\hline Freezing point $>-0.520^{\circ} \mathrm{C}$ & $0.4^{\mathrm{a}}$ & $10.1^{\mathrm{c}}$ & $1.8^{\mathrm{ab}}$ & $8.9^{\mathrm{c}}$ & $2.0^{\mathrm{b}}$ & $*$ & $* *$ & NS \\
\hline Total, high limits & $9.4^{\mathrm{a}}$ & $29.6^{\mathrm{c}}$ & $17.9^{\mathrm{b}}$ & $19.7^{\mathrm{b}}$ & $15.8^{\mathrm{b}}$ & NS & ** & * \\
\hline
\end{tabular}

a,b,c,d Significantly different within row, $P<0.05$. Levels of significance of fixed effects are indicated as $* P<0.05, * * P<0.01, * * * P<0.001$. $\mathrm{SCC}=$ somatic cell count; AMS = Automatic milking system.

improvement was seen on farms with the more recently installed AMS. Bulk-milk SCC was high and fluctuating in 1998 compared with conventional milking (Figure 4). The first farms with self-monitoring had higher SCC than the average of other Danish farms, but by the end of 1999, farms on the program were similar to the average of other Danish farms (Figure 4). New farms with AMS but still not enrolled in the self-monitoring program had higher bulk-milk SCC than the average of other farms. The farms on the program were able to keep the bulk-milk SCC at a lower level than farms not enrolled and also lower than when milking conventionally (Figure 5). This indicates that conventional farms may benefit from the self-monitoring program as well.

\section{Freezing Point}

The freezing point of the milk increased about $0.007^{\circ} \mathrm{C}$ after installation of AMS for both groups of farms $(P<0.05)$. The freezing point was not improved

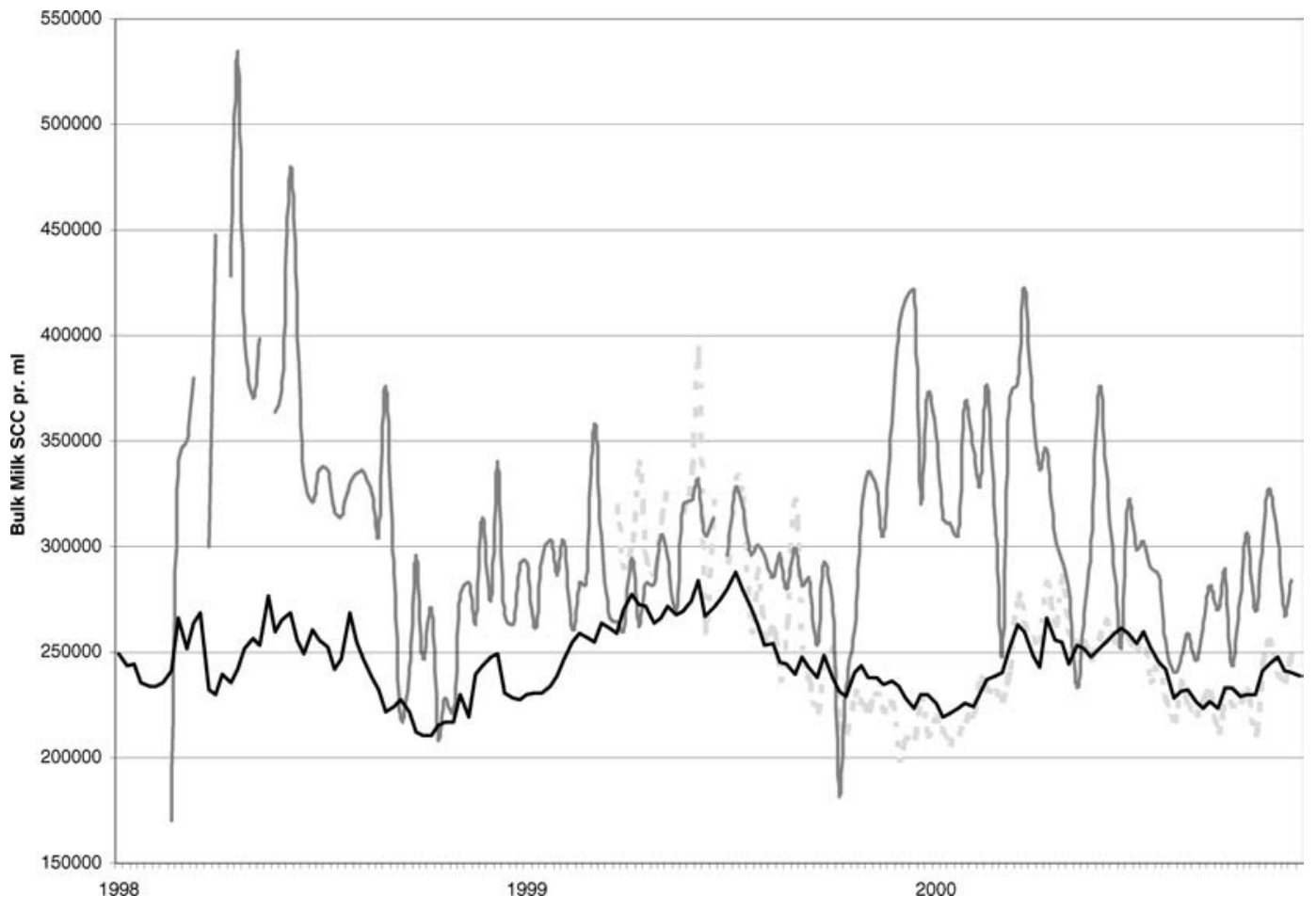

Figure 4. Geometric means of bulk-milk SCC of all Danish farms (black line), farms with automatic milking not enrolled in the selfmonitoring program (gray line), and farms with automatic milking enrolled in the self-monitoring program (dotted line). 


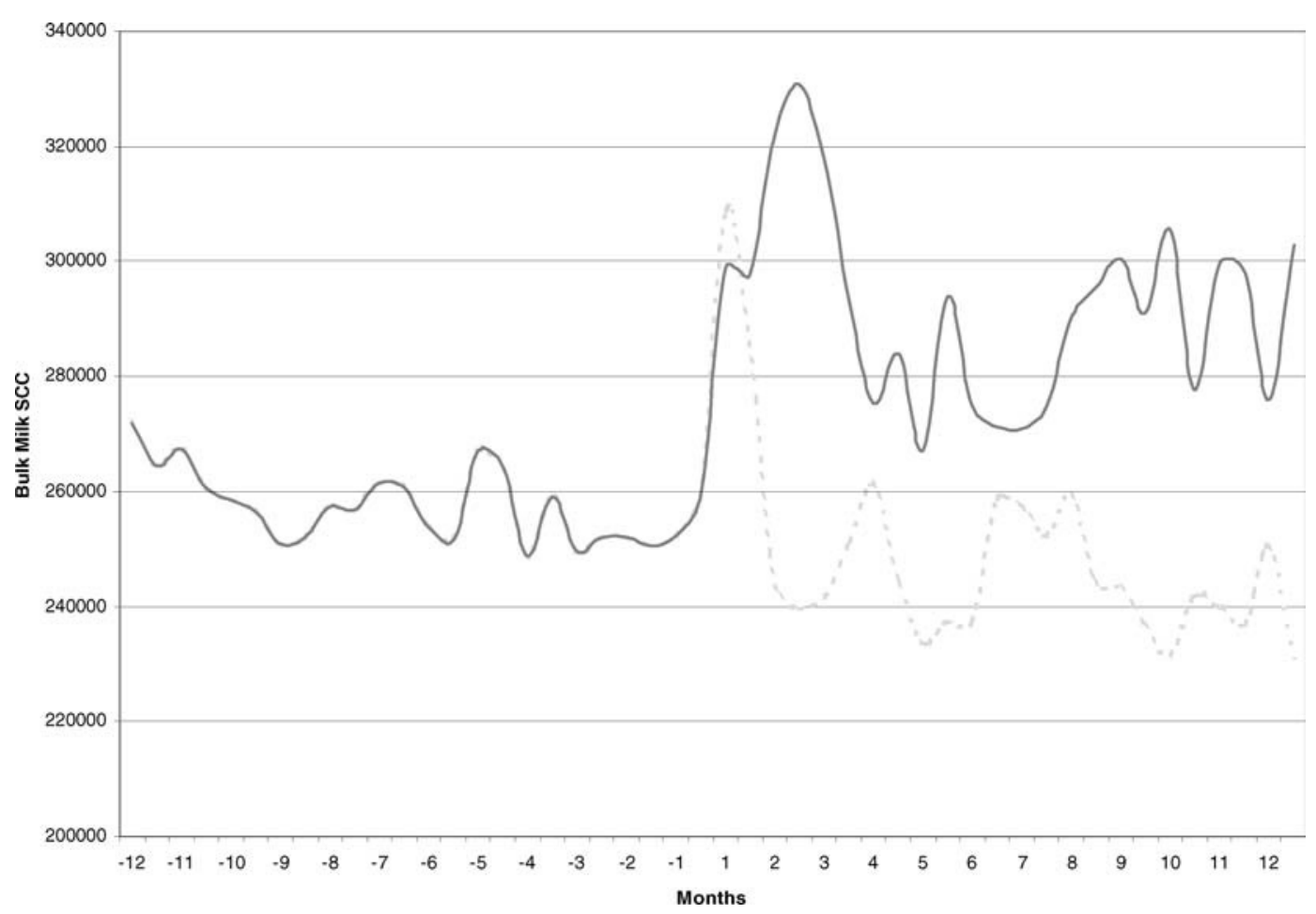

Figure 5. Least square means of bulk milk SCC the year before start of automatic milking of all farms and then split into farms with (dotted line) and without the self-monitoring program (gray line).

in the subsequent period (Table 3). The freezing point of bulk milk from AMS farms was constantly higher than from conventional farms (Figure 6). Reports from The Netherlands support these findings (Klungel et al., 2000; Vorst and Hogeveen, 2000). The average freezing point in milk from AMS farms is at too high a level and close to the legal limit of $-0.516^{\circ} \mathrm{C}$. Introduction of the self-monitoring program results in exclusion of milk from many infected cows. However, the AMS often still milks these cows during a treatment period, which requires more frequent cleaning of the milking equipment. The cleaning procedure leaves residues of water in tubes, connections, and tanks, which affects the freezing point. Detection of faults appears to be difficult, and more attention has to be given to self-drainage of the milking equipment and to procedures to blow water residues out of these systems.

\section{Failures in Milk Quality}

The weekly bulk-milk samples were surveyed with the intention of paying visits to the farmers in case of milk-quality failures. Pre-set limits were chosen, and the frequencies of milk-quality failures are reported in Table 4 . The percentage of bulk-milk samples being above the low and the high limits for a milk-quality failure was about $9 \%$ in the year milking convention- ally. These frequencies increased when milking automatically and most during the first 3 mo after start of AMS.

Total bacterial counts exceeded 30.000/mL (Danish premium class) and $100.000 / \mathrm{mL}$ (first class) in about $3 \%$ of the samples each milking automatically. The selfmonitoring program did not lower this frequency. Total bacterial count exceeded $100.000 / \mathrm{mL}$ in $1.0 \%$ of the samples in the year preceding automatic milking. Consequently, farmers have experienced deductions in the milk price more often milking automatically than by conventional milking. The increases in the frequency of samples exceeding TBC penalty limits are in agreement with Dutch experiences (Vorst and Hogeveen, 2000).

High cell counts of the bulk milk accounted for most of the failures, but the frequency of failures decreased over time (Table 4). Observations are in agreement with Table 3 and Figure 5. The frequency of cell counts $>400.000 / \mathrm{mL}$ was $8.7 \%$ in the year before automatic milking. Farms enrolled in the self-monitoring program experienced a small increase in number of deductions during the first 3 mo but then returned to the same frequency. Farms not enrolled in the program more than doubled the frequency of SCC failures in the first 3 mo and then improved within the next period, but not fully to the level when milking conventionally. The frequency of Danish milk-quality failures (15 to 20\%) 


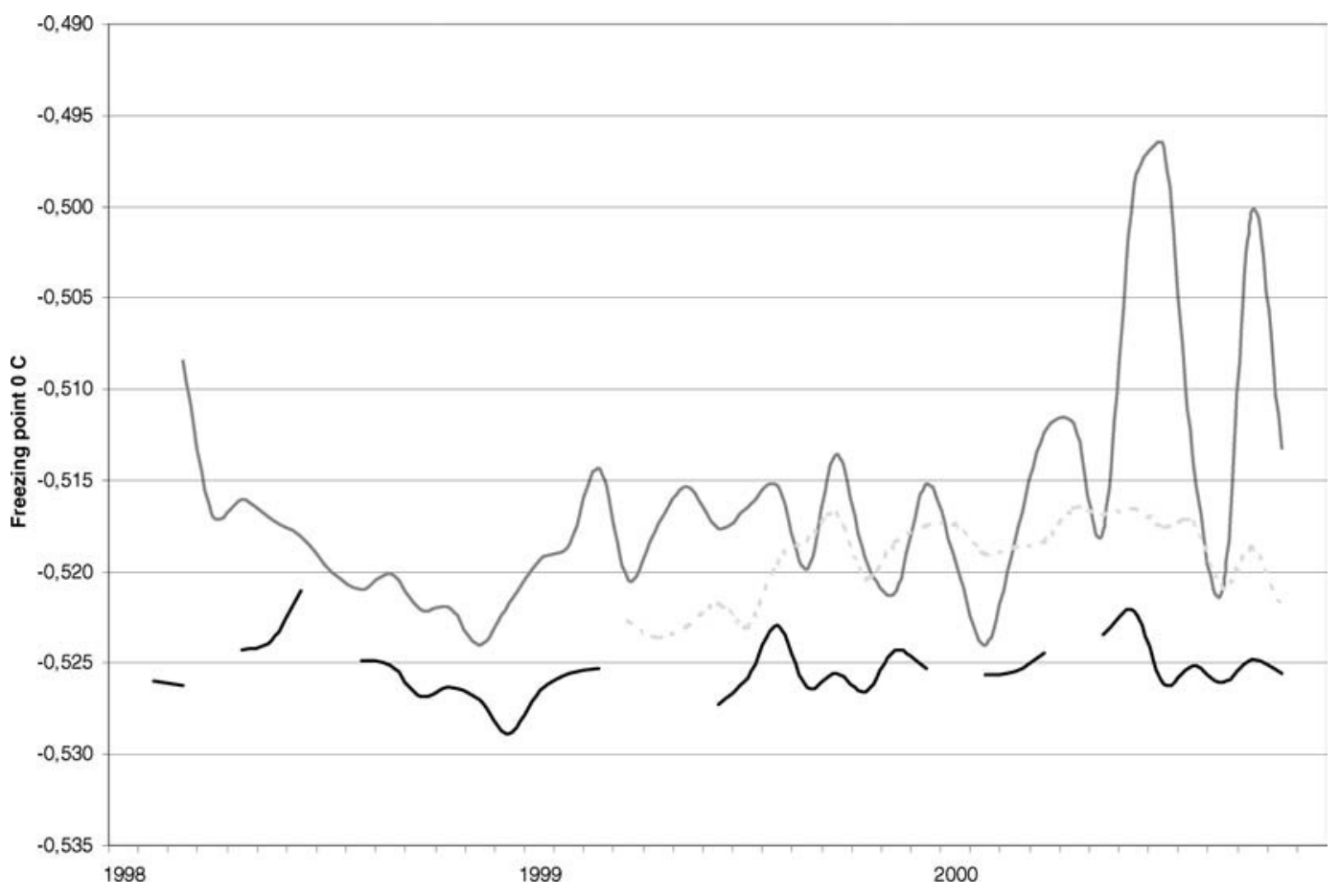

Figure 6. Mean freezing point of bulk milk of all Danish farms (black line), farms with automatic milking not enrolled in the selfmonitoring program (gray line), and farms with automatic milking enrolled in the self-monitoring program (dotted line).

was considerably higher than experienced by Dutch farmers (Vorst and Hogeveen, 2000), which could be expected considering the generally higher bulk-milk SCC level of Danish farms before introduction of AMS. The frequency of bulk-milk SCC passing 400.000 cells/ $\mathrm{ml}$ during conventional milking was comparable to the $10.5 \%$ found for the Province of Ontario (Sargeant et al., 1998).

The frequency of freezing points $>-0.516^{\circ} \mathrm{C}$ was unacceptably high when milking automatically, and the selfmonitoring program did not improve this. However, a lower frequency of the low-limit milk failures $\left(>-0.520^{\circ} \mathrm{C}\right)$ was observed on farms enrolled in the selfmonitoring program $(P<0.01)$. The frequency of high freezing points was increased more than eightfold compared with the $3.5 \%$ failures in the year preceding automatic milking. Likewise, an increase was observed in the percentages of samples exceeding the Dutch payment threshold (Vorst and Hogeveen, 2000) and for Canadian conditions (Rodenburg and Kelton, 2001).

The self-monitoring program was designed to put emphasis on cell count and, as such, the program is a success. Moreover, the frequency of freezing points between -0.520 and $-0.516^{\circ} \mathrm{C}$ was lowered as well. The total number of milk samples not reaching first class milk quality increased from 9.4 to $29.6 \%$ during the first 3 mo with AMS and no self-monitoring program
(Table 4). The closer follow-up by milk-quality inspectors and more attention from the farmers in this introductory period almost halved this frequency. Milk quality failed 286 times at the low level and 495 times at the high level out of a total of 2,808 milk samples of farms enrolled in the self-monitoring program. Fewer than $10 \%$ of the failures were followed up by a milkquality inspection visit mainly because higher priorities were given to the introductory visits, and many of the cases of high freezing points were consulted on the phone. It is reasonable to expect even better milk quality if all visits had been carried out.

\section{DISCUSSION AND CONCLUSION}

The self-monitoring program was generally well accepted by farmers and by the Danish distributors of AMS. The program significantly reduced the SCC of the bulk tank by helping farmers to detect cows with abnormal foremilk at the start of automatic milking and then to work professionally with the alarm lists. None of the automatic milking systems included in this study sorted milk according to SCC, and it is an individual management decision as to which milk should be delivered for consumption. The higher bulk-milk SCC and frequency of milk-quality failures of farms not yet enrolled in the self-monitoring program show that addi- 
tional support to detect clinically infected cows is needed. The effect of the program will depend on the starting level of bulk-milk SCC, which is highlighted by the difference in penalty frequencies of Danish and Dutch AMS farms and, as such, probably will be beneficial for all farms with high bulk-milk SCC. We can not conclude directly that the reduction is due to application of the program. What probably is just as important is the focus on the topic and change of attitude of farmers. The province of Ontario has run a program for reduction of bulk-milk SCC, and reduction of the penalty limit reduced the mean bulk-milk SCC and lowered the frequency of exceeding penalty limits (Sargeant et al., 1998). There has been a focus on bulk milk SCC for several years in many countries, and many farmers know that high bulk-milk SCC are due to inclusion of milk from clinically infected cows. Still not all farmers forestrip and check for abnormalities and, likewise, checking of foremilk is not performed in AMS as well. Even though the general penalty limits influence the mean bulk-milk SCC and thereby the frequency of cows with clinically mastitis with milk for the bulk tank, there seems to be a need for additional survey and guidance for lowering this frequency. It is important for the industry to prove that milk quality of farms with AMS can be as good as for conventional farms. The selfmonitoring program can help in this process by putting more focus on detection of cows with visually abnormal foremilk and high CMT-score, but an expected effect would not be unique to farms with AMS only.

The self-monitoring program did not lower the frequency of high bacterial counts or freezing points in the bulk milk. We need to put more emphasis on these matters but suggest that technical as well as management failures are causing these high numbers. We will reconsider the program and the additional visits in case of failures in total bacterial count and freezing point because general technical improvements probably are needed in the first place. It is important to consider how failures in milk quality should be consulted. The program has been adopted by Sweden and Norway, partly by Germany, and is under consideration for controlling milk quality in USA for farms milking automatically (Leitzke, 2002).

In conclusion, bulk-milk TBC, spores of anaerobes, SCC, and freezing point increased on Danish farms going from conventional to automatic milking. The frequency of milk-quality deductions about doubled. Farms where the self-monitoring program was introduced reduced bulk-milk SCC almost back to the level as before AMS and reduced their frequencies of milkquality failures significantly. Possibly, the application of the program and special focus on cows with clinical mastitis may reduce bulk-milk SCC for other countries and AMS and may be beneficial for conventional farms as well.

\section{ACKNOWLEDGMENTS}

We are grateful to the dairy farmers and the Danish distributors of AMS for providing access to the milkquality data and data of installation of AMS. The study was supported by the Directorate for Food, Fisheries, and Agri Business, Denmark.

\section{REFERENCES}

De Mol, R. M. 2000. Automated detection of oestrus and mastitis in dairy cows. Ph.D. thesis, Wageningen University, The Netherlands. $177 \mathrm{pp}$.

Hamann, J., and A. Zecconi. 1998. Evaluation of the electrical conductivity of milk as a mastitis indicator. Bulletin of IDF No. 334, $26 \mathrm{pp}$.

Hogeveen, H., Y. van der Vorst, W. Ouweltjes, and B. A. Slaghuis. 2001. Automatic milking and milk quality: A European perspective. Pages 152-162 in Proc. 40th Natl. Mastitis Council Ann. Meet. Madison, WI, USA.

IDF. 1969. Bulletin Technic d'Information no. 239.

Jepsen, L., and M. D. Rasmussen. 2000. Milk quality on Danish farms with automatic milking systems. Natl. Mastitis Council Ann. Meet. 39:181-182.

Klungel, G. H., B. A. Slaghuis, and H. Hogeveen. 1998. Weerk aan de robotwinkel. Melkkvaliteit bij automatisch melken verdient anndact. Veetelt, August, pp. 888-890.

Klungel, G. H., B. A. Slaghuis, and H. Hogeveen. 2000. The effect of the introduction of automatic milking systems on milk quality. J. Dairy Sci. 83:1998-2003.

Knappstein, K., J. Reichmuth, and G. Suhren. 1998. Ausgewählte milchhygienische Aspekte beim Einsatz von Melkrobotern-Beobachtungen in einem Praxisbetrieb. Pages 263-268 in Bericht 39. Arbeitstagung des Arbeitsgebietes Lebensmittelhygiene der Deutschen Veterinärmedizinischen Gesellschaft (DVG) vom 22.25.9 in Garmish-Partenkirchen, Germany.

Leitzke, T. 2002. Automatic milking systems (AMS) study in the United States. Proposal \# 146 NCIMS. Preconference Regulatory Workshop. The First North American Conference on Robotic Milking. Toronto, CA. 53-57 and appendix.

Lind, O., A. H. Ipema, C. de Koning, T. T. Mottram, and H.-J. Hermann. 2000. Automatic milking. International Dairy Federation, Brussels, Belgium. Bulletin 348/2000, 1-14.

Nielen, M., Y. H. Schukken, A. Brand, S. Haring, and R. T. FerwerdaVan Zonnenveld. 1995. Comparison of analysis techniques for online detection of clinical mastitis. J. Dairy Sci. 78:1050-1061.

Rasmussen, M. D., and L. Jepsen. 2000. Test of automatic milking systems in Denmark and self-monitoring of milk quality. Natl. Mastitis Council Ann. Meet. 39:1183-1185.

Rodenburg, J., and D. F. Kelton. 2001. Automatic milking systems in the North America: issues and challenges unique to Ontario. Pages 163-169 in Proc. 40th Natl. Mastitis Council Ann. Meet. Madison, WI.

Sargeant, J. M., Y. H. Schukken, and K. E. Leslie. 1998. Ontario bulk milk somatic cell count reduction program: progress and outlook. J. Dairy Sci. 81:1545-1554.

SAS Institute Inc. 1996. SAS/STAT Software: Changes and enhancements, Release 6.12. SAS Institute, Inc., Cary, NC.

Vorst, Y.v.d., and H. Hogeveen. 2000. Automatic milking systems and milk quality in the Netherlands. Pages 73-82 in Proc. Int. Symp. Robotic Milking. H. Hogeveen and A. Meijering, ed., Wageningen Pers, Lelystad, The Netherlands. 